Archives of Agriculture and Environmental Science

\title{
Effects of nitrite concentrations on soil and certain vegetables irrigated with wastewater of Kubanni stream in Zaria, Kaduna State, Nigeria
}

\author{
S.O. Oladeji ${ }^{1 *}$ (D) and M.D. Saeed ${ }^{2}$
}

${ }^{1}$ Department of Polymer Technology, Hussaini Adamu Fed. Polytechnic, Kazaure, Jigawa State, NIGERIA

${ }^{2}$ Department of Chemistry, Bayero University Kano, Kano State, NIGERIA

*Corresponding author's E-mail: saheedilori75@gmail.com

\section{ARTICLE HISTORY}

Received: 30 April 2018

Revised received: 09 May 2018

Accepted: 15 May 2018

\section{Keywords}

\section{ANOVA}

Kubanni stream

Nitrite concentration

Soil

Vegetable

Wastewater

\begin{abstract}
The study examined the effect of nitrite ions in wastewater, soil and vegetables through man-made activities. Nitrite level was determined in wastewater, soil and vegetables viz., spinach (Amaranthus hybridus), lettuce (Lactuca sativa), cabbage (Brassica oleracea), carrot (Daucus carota), okra (Hibiscus esculentus), onion (Allium cepa) and tomato (Lycopersicon esculenetum) collected on seasonal basis along Kubanni stream in Zaria. The levels of nitrate in the wastewater, soils and vegetables were determined using UV/Visible and Smart Spectrophotometer. Results obtained show that nitrite concentrations ranged from 12.05 $53.21 \mathrm{mg} / \mathrm{L}$ in the year 2013 and $1.58-17.09 \mathrm{mg} / \mathrm{L}$ in the year 2014 for wastewater, soil had concentrations ranged from $0.05-6.40 \mathrm{mg} / \mathrm{kg}$ in the year 2013 and $0.90-9.90 \mathrm{mg} / \mathrm{kg}$ for year 2014 while the vegetable had levels of $3.80-23.65 \mathrm{mg} / \mathrm{kg}$ in the year 2013 and $7.48-27.15$ $\mathrm{mg} / \mathrm{kg}$ in the year 2014. Statistical tests indicated no significant difference in nitrite levels across the locations and seasons for wastewater, soil and vegetables evaluated. Correlation results for these two years indicated low $(r=0.399, r=0.275)$ relationship for wastewater and vegetables whereas negative $(r=-0.290)$ relationship noticed for the soil. The results showed that irrigating the farmland with untreated wastewater has negative consequence on the crops grown with it and thus, cultivation of wastewater irrigated soils and vegetables should be continuously monitored to stop any possible hazard.
\end{abstract}

(C)2018 Agriculture and Environmental Science Academy

Citation of this article: Oladeji, S.O. and Saeed, M.D. (2018). Effects of nitrite concentrations on soil and certain vegetables irrigated with wastewater of Kubanni stream in Zaria, Kaduna State, Nigeria. Archives of Agriculture and Environmental Science, 3(2): 123-130, https://dx.doi.org/10.26832/24566632.2018.030204

\section{INTRODUCTION}

Long term use of polluted water for cultivation of vegetables may result in the accumulation of heavy metals and anions in the agricultural soils, affecting microbial activities as well as their transfer to various crops under cultivation with level of contamination that exceed permissible level (Thompson and Kelly, 2003). A reduction in nitrite content can add value to vegetable products already known for their nutritional and therapeutic properties (Santamaria, 2006). Therefore, it is important to adopt appropriate strategies and determine the role of individual physiological factors in the process of vegetable growth in order to limit accumulation of nitrate, nitrite, phosphate and sulphate in vegetables as their excess have nega- tive effects on consumers. These could achieve by adopting lesser use of fertilizer application, reduce the potential degradation of soil from overgrazing and water resources control are needed to achieve this objective. Nitrogen, phosphorus and potassium (NPK) fertilizers are used widely in vegetable agriculture resulting in accumulation of nitrate, phosphate and sulphate in vegetable plants, if the rate of its uptake exceeds the rate of its reduction to ammonium ions, the excess which is water soluble in the soil can leach into groundwater and cause its contamination. The some heavy metals such as $\mathrm{Cu}, \mathrm{Zn}, \mathrm{Mn}$ and Fe uptake by the plants specifically the leafy vegetables is an avenue of their entry into the human food chain with harmful effects on health (Luo et al., 1983; Oladeji, 2017). As reported by McCall and Willumsen (1998) high rates of nitrate application, increase 
the plant nitrate content without increasing the yield. Thus, growers who apply extreme fertilizers to confirm that nitrogen is not limiting for plant growing are unlikely to achieve any gain in terms of yield but increase the nitrate content of crops to the level potentially toxic to humans. The levels of anions in soils through fertilizer application depend on the origin of fertilizer and manufactured processes (Devkota and Schmidt, 2000). Moreover, an increasing awareness in terms of the importance of vegetables and fruits to human diet suggests that the monitoring of anion levels in food crops should be carried out frequently.

Nitrite $\left(\mathrm{NO}_{2}{ }^{-}\right)$is inorganic ions that occur naturally and are part of the nitrogen cycle. Nitrite oxidizes easily into nitrate by Nitrobacter thus, nitrate occurs more frequently in ground and surface water. Microbes break down animal and human organic wastes in soil and water to ammonia. This breakdown process of converting organic wastes into ammonia, which then oxidizes into nitrite and nitrate are referred to as Nitrification process done by Nitrosomonas and Nitrobacter bacteria (Grubben, 1976). Vegetables are having greater nitrate content than do other plants due to nitrogen fixation and is one way of exposing to excessive nitrite and nitrate in foods (ATSDR, 2011). Also, exposure to high amounts of nitrites from soil and water contaminated arise from runoff of nitrogen-containing fertilizers (e.g., potassium nitrite and ammonium nitrite) as being reported in literatures Akan (et al., 2009; Oladeji and Saeed, 2018). Excessive nitrite exposure by people resulted in acute methemoglobinemia, a serious health condition. Methemoglobinemia is a state in which there is an excess of methemoglobin in the blood. Methemoglobinemia can cause cyanosis (blue skin) of limbs/ trunk, weakness and rapid heart rate (ATSDR, 2007). Severe methemoglobinemia results in lethargy, loss of consciousness, irregular heartbeat, shock, convulsions, coma, and even death (Reddy and Menary, 1990). Akan et al. (2009) examined the heavy metals and anions levels in some vegetable samples grown within the vicinity of Challawa Industrial area and reported chromium level as (1.00-9.23 $\mu \mathrm{g} / \mathrm{g})$ as highest in concentration among the analyzed vegetable while copper (0.89-2.17 $\mu \mathrm{g} /$ g) concentration was the least. The concentrations of the anions were $40-1300 \mu \mathrm{g} / \mathrm{g}$ for nitrite, $65-1500 \mu \mathrm{g} / \mathrm{g}$ for nitrate, $122-$ $765 \mu \mathrm{g} / \mathrm{g}$ for sulphate and $12-60 \mu \mathrm{g} / \mathrm{g}$ for phosphate respectively. They concluded that the leaves of vegetables contained higher heavy metals and anion concentrations than roots and stems. Therefore, addition of excess heavy metals and ions produce various negative effects in the soils as well as the vegetables grown through the wastewater irrigation. Keeping in view, the present study was aimed to evaluate the levels of nitrite in wastewater, soil and vegetable samples grown along Kubanni stream channels in Zaria, Kaduna State, Nigeria.

\section{MATERIALS AND METHODS}

\section{Collection of wastewater and soil samples}

Wastewater samples from Kubanni stream were obtained on a four-month basis at point of inlet into the river at five different points along the stream channels for the period of 2013 and 2014 (Figure 1). Sampling was conducted in the harmattan, dry and rainy seasons from January 2013 to September 2014. Wastewater samples were collected using composite sampling in a polyethylene plastic containers that were previously cleaned by washing in non-ionic detergent, rinsed with tap water and soaked in $0.1 \mathrm{M} \mathrm{HNO}_{3}$ for 24 hours and finally rinsed with deionized water prior to usage (Ademoroti, 1996). Sample bottles used were rinsed with sampled water three times and then filled to the brim at a depth of one meter below the wastewater from each of the five designated sampling points. Wastewater sample bottles were labelled, stored in ice-blocked coolers and transported to the laboratory while in the Analytical laboratory; they were stored in the refrigerator at about $4{ }^{\circ} \mathrm{C}$ prior to the analysis (APHA, 2012).

Soil samples were collected at three depths $(0-5 \mathrm{~cm}, 5-10 \mathrm{~cm}$ and $10-15 \mathrm{~cm}$ ) from both sides of the river banks by using spiral auger of $2.5 \mathrm{~cm}$ diameter. Soil samples were randomly sampled and bulked together to form a composite sample from each designated point. They were then put in clean plastic bags, labelled and transported to the laboratory.

\section{Collection of vegetable samples}

The full grown vegetable of spinach (Amaranthus hybridus), lettuce (Lactuca sativa), cabbage (Brassica oleracea), carrot (Daucus carota), okra (Hibiscus esculentus), onion (Allium cepa) and tomato (Lycopersicon esculenetum) were randomly handpicked from various garden plots along Kubanni stream channels using hand-gloves, bulked together to form a composite sample, wrapped in a big brown envelopes, labelled accordingly and transported to the laboratory.

\section{Sample processing and treatment}

Wastewater sample bottles were kept in a refrigerator set at $4^{\circ}$ C prior to analysis (APHA, 2012). Soil samples were air-dried, crushed and sieved through $2 \mathrm{~mm}$ mesh sieve. The soil samples were then put in clean plastic bags, sealed and labelled accordingly (Musa et al., 2009). Each vegetable samples were washed with tap water, followed by deionized water, air dried in the laboratory, grounded to powder and sieved using $250 \mu \mathrm{m}$ sieve (Munson and Nelson, 1990).

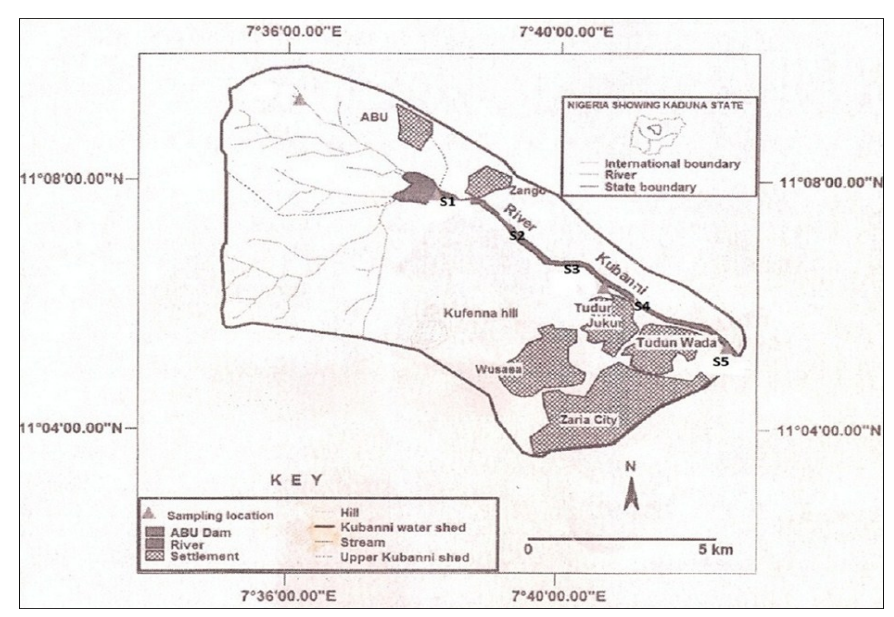

Figure 1. Map of sampling sites (Sources: Oladeji, 2017). 
Determination of nitrite in wastewater

Ten centimetre cube of the wastewater from each sample was pipetted into a sample container. The content of one sachet of the reagent powder pillow (NitriVer 3 Nitrite) was added, stoppered and the cell was shaken to dissolve the powder. The concentration was read at $507 \mathrm{~nm}$ after 20 minutes using a portable Data Logging Spectrophotometer (HACH DR\2010). The result in $\mathrm{mg} / \mathrm{L}$ nitrite expressed as $\left(\mathrm{NO}_{2}{ }^{-}-\mathrm{N}\right)$ was displayed. The amount of nitrite is determined by multiplying with a conversion factor of 3.284 (APHA, 2012).

\section{Determination of nitrite in soil samples}

The concentration of the chloride in the soil samples filtrates were firstly determined, the readings of chloride were divided by 10 and known amount of $0.02 \mathrm{M} \mathrm{Ag}_{2} \mathrm{SO}_{4}$ were added equivalent to the amount of chloride in the filtrates. $5 \mathrm{~cm}^{3}$ aliquots were then taken into centrifuge test tube and diluted to $10 \mathrm{~cm}^{3}$ with deionized water. The tubes were centrifuged for 10 minutes until the solutions were clear. $5 \mathrm{~cm}^{3}$ of the clear solutions were taken in glass evaporating dish, placed on water bath, evaporated to dryness and then cooled. $1 \mathrm{~cm}^{3}$ of phenoldisulphonic acid solution was added to individual tubes and analyzed as described by Musa et al. (2009). The absorbance was taken at $507 \mathrm{~nm}$ using JENA Model UV/Visible Spectrophotometer and their concentrations were extrapolated from calibration curve.

\section{Determination of nitrite in the vegetable samples}

The concentrations of nitrite analyzed in each of the vegetable samples were carried out using Smart Spectro spectrophotometer (APHA, 2012). The method is based on diazotization of sulphanilic acid by nitrite in acid solution and the coupling of the resulting diazonium compound with alpha-naphthyl-amine to give a red azo-dye (Ademoroti, 1996). Vegetable samples solutions were prepared by grinding each dried sample into powder. A known amount ( $1 \mathrm{~g})$ of the powdered sample was transferred into $100 \mathrm{~cm}^{3}$ flask and soaked with $50 \mathrm{~cm}^{3}$ of deionized water. The flasks were capped and shaken for 30 minutes, then filtered into another $100 \mathrm{~cm}^{3}$ volumetric flasks and the volume made to the mark with deionized water. Nitrite was determined spectrophotometrically using standard cadmium reduction method as described by Radojevic and Bashkin (1999).

\section{Statistical analysis}

The results of nitrite in wastewater, soil and vegetables analyzed were expressed in form of bar-charts. The results obtained were subjected to one way analysis of variances (ANOVA) and Pearson Product Moment Correlations (PPMC) using Statistical Package for the Social Sciences (SPSS) 20.0 version software. Null hypothesis was adopted and this was set at $95 \%$ confidence mean level to check if there is significant difference in the concentrations of nitrite analyzed. Statistical decision for Pearson correlation coefficients $(r)$ were in accordance to Robert (1992).

\section{RESULTS AND DISCUSSION}

\section{Characteristics of wastewater}

Figure 2 shows nitrite concentrations in wastewater from Kubanni stream channels. The concentrations determined were in the range of $12.05-53.21 \mathrm{mg} / \mathrm{L}$ for the year 2013. Highest concentration of $53.21 \mathrm{mg} / \mathrm{L}$ was obtained at Kwangila sampling site during the harmattan season followed by $42.78 \mathrm{mg} / \mathrm{L}$ at Tundun-wada while the least level of $12.05 \mathrm{mg} / \mathrm{L}$ was obtained in the rainy season at Tundun-wada. Elevated levels of nitrite during harmattan and dry seasons could be as a result of indiscriminate disposal of animal and human faeces from nearby houses into sampling sites as suggested by lkemoto et al. (2002). Other sampling sites with high concentrations of nitrite were; Sabon-gari (38.63 mg/L), Industrial area along Jos road (32.28 $\mathrm{mg} / \mathrm{L}$ ) both in the dry season and Unguwa-fulani $(24.68 \mathrm{mg} / \mathrm{L}$ ) during the harmattan season. Rainy season showed low levels of nitrite in the year 2013 as indicated in Figure 2 and this might be attributed to dilution effects as suggested by Chapman (1997). The concentrations obtained for nitrite in wastewater for year 2014 were in the range of 1.58 - $17.09 \mathrm{mg} / \mathrm{L}$. Lowest level of $1.58 \mathrm{mg} / \mathrm{L}$ was found at Sabon-gari sampling site whereas the highest concentration $(17.09 \mathrm{mg} / \mathrm{L})$ was obtained in the dry season at Tundun-wada. Other locations with high levels of nitrite were; Unguwa-fulani (16.74 mg/L) and Kwangila (13.20 $\mathrm{mg} / \mathrm{L}$ ) both in the dry season, Industrial area along Jos road had level of $12.58 \mathrm{mg} / \mathrm{L}$ during harmattan season, Sabon-gari showed $12.42 \mathrm{mg} / \mathrm{L}$ in the same harmattan season and 11.42 $\mathrm{mg} / \mathrm{L}$ at Industrial area along Jos road. In the year 2014, nitrite showed highest accumulation in the dry season (9.87 - 17.09 $\mathrm{mg} / \mathrm{L}$ ) while the least level was observed in the rainy season $(1.58-4.21 \mathrm{mg} / \mathrm{L})$. High levels of nitrite during the dry season might be connected to availability of denitrifying bacteria that convert nitrate to nitrite in the presence of light intensity from sun as suggested by Heckman (2002). Comparing the results obtained in the year 2013 with that of year 2014, it was revealed that in harmattan season of 2013 , the results indicated higher concentration of nitrite $(13.08$ - $53.21 \mathrm{mg} / \mathrm{L})$ than harmattan season of the year $2014(3.79-12.58 \mathrm{mg} / \mathrm{L})$. Likewise, dry season of 2013 (19.64 - $52.41 \mathrm{mg} / \mathrm{L})$ had more accumulation of nitrite in wastewater than dry season of the year 2014 (9.87 - $17.09 \mathrm{mg} / \mathrm{L})$. In the same way, rainy season of the year 2013 (12.05 - $20.64 \mathrm{mg} / \mathrm{L}$ ) indicated more accumulation of nitrite in wastewater than rainy season of the year 2014 $(1.58-4.21 \mathrm{mg} / \mathrm{L})$. Low levels of nitrite in the year 2014 year could be as a result of flooding in the year 2013; this led to heavy erosion which might have washed away most of the needed nitrogenous compounds in wastewater as suggested by Guillard et al. (1999).

\section{Characteristics of wastewater irrigated soil}

Figure 3 presents nitrite concentrations in soil from Kubanni stream channels. The concentrations determined were in the range of $0.05-6.40 \mathrm{mg} / \mathrm{Kg}$ for the year 2013 . Highest level of 
$6.40 \mathrm{mg} / \mathrm{Kg}$ was found at Sabon-gari followed by $2.44 \mathrm{mg} / \mathrm{Kg}$ at Industrial area along Jos road and this was closely followed by $2.15 \mathrm{mg} / \mathrm{Kg}$ at Tundun-wada, all these results were obtained in the harmattan season whereas the least level of $0.05 \mathrm{mg} / \mathrm{Kg}$ was obtained at Industrial area along Jos road and Sabon-gari sampling site during the rainy seasons. High levels of nitrite observed during harmattan season could be as a result of fertilizer accumulations in soil due to prolong use of the sites for farming as suggested by Abdu et al. (2011). A decline in nitrite levels was noticed from dry season to rainy seasons which could be related to dilution effects as suggested by Chapman (1997). The concentrations obtained for nitrite in the year 2014 were in the range of $0.90-9.90 \mathrm{mg} / \mathrm{Kg}$. High level of $9.90 \mathrm{mg} / \mathrm{Kg}$ was found at Tundun-wada during the dry season followed by 8.01 $\mathrm{mg} / \mathrm{Kg}$ in the rainy season at Kwangila sampling site and closely followed by $6.40 \mathrm{mg} / \mathrm{Kg}$ at Industrial area along Jos road in the harmattan season whereas low level of nitrite in soil was noted at Tundun-wada $(0.09 \mathrm{mg} / \mathrm{Kg})$ during rainy season. High concentrations of nitrite recorded in all seasons for the year 2014 could be as a result of excessive application of fertilizers than usual as a result of flooding experienced in the year 2013 as suggested by Oyedele et al. (2006). Other sites with high concentrations of nitrite were; Unguwa-fulani $(5.52 \mathrm{mg} / \mathrm{Kg}$ ), Sabon-gari $(5.30 \mathrm{mg} / \mathrm{Kg}$ ) and Tundun-wada sampling site (3.54 $\mathrm{mg} / \mathrm{Kg}$ ). Comparing the results of the year 2013 and in the year 2014 for nitrite levels in soil, it was observed that in harmattan season of year 2013, the results indicated lower concentration $(1.31-6.40 \mathrm{mg} / \mathrm{Kg})$ than harmattan season of the year 2014 $(2.04-6.40 \mathrm{mg} / \mathrm{Kg}$ ) whereas dry season of the year 2014 (1.61 - $9.90 \mathrm{mg} / \mathrm{Kg}$ ) showed more nitrite accumulation in soil than dry season of the year $2013(0.05-1.32 \mathrm{mg} / \mathrm{Kg})$. In the same way, rainy season of the year $2014(1.55-8.01 \mathrm{mg} / \mathrm{Kg})$ had higher level of nitrite than rainy season of the year 2013 (0.05- 1.12 $\mathrm{mg} / \mathrm{Kg}$ ). Elevated levels of nitrite in the year 2014 could be as a result of wastewater use for irrigation combined with excessive application of fertilizers as suggested by Uwah et al. (2007) and Sodipo et al. (2012).

\section{Content of nitrate in vegetables}

Nitrite concentrations in vegetables obtained along Kubanni stream channels is presented in Figure 4. The concentrations determined were in the range of $0.40-12.05 \mathrm{mg} / \mathrm{Kg}$ for the year 2013. Highest level of $12.05 \mathrm{mg} / \mathrm{Kg}$ was obtained in spinach followed by $10.31 \mathrm{mg} / \mathrm{Kg}$ in cabbage and closely followed by $8.32 \mathrm{mg} / \mathrm{Kg}$ in okra all planted in the dry season whereas the least concentration of $0.40 \mathrm{mg} / \mathrm{Kg}$ was found in carrot cultivated in the rainy season. High levels of nitrite in vegetables during dry season might be attributed to excessive use of wastewater coupled with excessive application of fertilizers as suggested by Uwah et al. (2007). Other vegetables with high nitrite concentrations were; onion ( 8.60 and $7.81 \mathrm{mg} / \mathrm{kg}$ ) during the harmat$\tan$ and dry seasons, spinach $(7.50$ and $7.00 \mathrm{mg} / \mathrm{Kg}$ ) in both harmattan and rainy seasons, cabbage $(4.00 \mathrm{mg} / \mathrm{Kg})$ planted in the rainy season and tomato $(3.64 \mathrm{mg} / \mathrm{Kg})$ in the dry season. Vegetables analyzed had concentrations in the range of 0.90 -
$44.07 \mathrm{mg} / \mathrm{Kg}$ for the year 2014. Highest level of $44.07 \mathrm{mg} / \mathrm{Kg}$ was found in okra followed by spinach $(34.10 \mathrm{mg} / \mathrm{Kg})$ and this was closely followed by tomato $(33.13 \mathrm{mg} / \mathrm{Kg})$ all cultivated in the rainy season while the lowest concentration of $0.90 \mathrm{mg} / \mathrm{Kg}$ was recorded in onion. Elevated levels of nitrite during rainy season could be as a result of excessive application of manure and fertilizers than usual resulting in accumulation of nitrate and this was reduced to nitrite by catalyzed enzyme (nitrate reductase) as suggested by Durner and Klessing (1999). Other vegetables with high nitrite levels were; lettuce $(27.00 \mathrm{mg} / \mathrm{Kg})$, carrot $(24.01 \mathrm{mg} / \mathrm{Kg})$, cabbage $(23.40 \mathrm{mg} / \mathrm{Kg}$ ) all recorded in the rainy season; spinach had the level of $16.10 \mathrm{mg} / \mathrm{Kg}$ while 14.60 $\mathrm{mg} / \mathrm{Kg}$ was found in cabbage in the harmattan season. Comparing the results obtained in the year 2013 with that of the year 2014 for nitrite level, it was revealed that rainy season of the year 2014 indicated higher levels of nitrite ions (8.87 - 44.07 $\mathrm{mg} / \mathrm{Kg})$ than rainy season of the year $2013(0.40-7.60 \mathrm{mg} / \mathrm{Kg})$. Likewise, harmattan season of the year 2014 (0.90 - 16-10 mg/ $\mathrm{Kg}$ ) showed high concentration of nitrite ion in vegetables than harmattan season of the year $2013(0.50-8.60 \mathrm{mg} / \mathrm{Kg})$ whereas dry season of the year $2014(2.72-8.92 \mathrm{mg} / \mathrm{Kg})$ showed less accumulation of nitrite than dry season of the year 2013 (1.43 $10.31 \mathrm{mg} / \mathrm{Kg}$ ). Uwah et al. (2007) reported $8.18-199.42 \mathrm{mg} / \mathrm{Kg}$ as nitrite levels in vegetables cultivated with wastewater which was higher than results obtained in this study.

Analysis of variance was conducted to establish difference in nitrite levels among the sampling locations between the year 2013 and 2014. Statistical analysis showed their mean with standard deviation as thus; Kwangila (23.075 \pm 20.528$)$, Unguwa -fulani (20.060 \pm 17.378$)$, Sabon-gari (16.092 \pm 12.578$)$, Tundunwada (12.635 \pm 8.380$)$ and Industrial-area along Jos road (14.905 \pm 9.977$)$, respectively. From ANOVA data presented in Table 1, the values of $P=0.737>0.050$ indicated that there is no significant difference in nitrite levels across the sampling sites. Nitrite concentrations were also examined across the seasons to establish their differences. Their mean with standard deviation showed these; harmattan season of the year 2013 (28.294 \pm 23.163$)$, dry season of the year 2013 (18.222 \pm 13.736$)$, rainy season of the year $2013(12.624 \pm 5.493)$, harmattan season of the year $2014(15.606 \pm 12.318)$, dry season of the year $2014(11.614 \pm 7.763)$ and rainy season of the year 2014 (17.760 \pm 15.099$)$, respectively. Table 1 reveals $P=0.498>$ 0.050 this means that there is no significant difference in nitrite concentrations across the seasons. This might be due to sampling areas are falling within the same vicinity thereby their soil geological formations are similar irrespective of change in seasons as suggested by Farooq et al. (2008). The Pearson Product Moment Correlation (PPMC) for evaluating the relationship between nitrite levels in wastewater for the year 2013 and 2014 is indicated in Table 2. The statistical analysis indicated that the mean with standard deviation level for nitrite was $26.481 \pm 14.043$ in 2013 while $8.226 \pm 5.453$ was in 2014 . The Pearson correlation $(r)=0.399$, degree of freedom $(d f)=13$ and the values of $\mathrm{P}=0.140>0.050$ means that there was very low relationship between nitrite levels in wastewater for the 
years 2013 and 2014, respectively.

From the ANOVA data showed in Table 3, the values of $P=$ $0.990>0.050$ indicated that there is no significant difference in nitrite levels across the sampling sites. The sampling locations revealed these statistical analysis as thus; Kwangila (2.883 \pm 2.654$)$, Unguwa-fulani (2.210 \pm 1.669$)$, Sabon-gari (2.580 \pm 2.679$)$, Tundun-wada (2.873 \pm 3.659$)$ and Industrial-area along Jos road $(2.422 \pm 2.054)$, respectively. Their mean values are relatively close to one another thereby no significant difference is justified. Also, the data presented in Table 3 indicates that the values of $P=0.760>0.050$ showed that there is no significant difference in nitrite concentrations across the seasons. Their results showed these; harmattan season of the year 2013 (1.702 \pm 1.299$)$, dry season of the year $2013(3.300 \pm 3.636)$, rainy season of the year $2013(2.524 \pm 2.470)$, harmattan season of the year 2014 (3.302 \pm 2.007$)$, dry season of the year 2014 $(1.498 \pm 0.690)$ and rainy season of the year 2014 (3.236 \pm 3.740$)$, respectively. These values are relatively close to one another and may be attributed to anthropogenic activities in the sampling sites as suggested by Butu (2013). Table 4 presents Pearson Product Moment Correlation for nitrite levels in soil between the year 2013 and 2014. Statistical data showed mean with standard deviation level for nitrite to be $1.407 \pm 1.548$ in 2013 while $3.781 \pm 2.663$ was obtained in 2014 with the degree of freedom $(\mathrm{df})=13$, Pearson correlation $(r)=-0.290$ and as per the values of $P=0.456>0.050$ which indicated that there is negative relationship between nitrite levels in soil for the year 2013 to that of the year 2014. The result is justified since there was high application of fertilizers and manures in the year 2014 which might increase the nitrite levels as suggested by Sodipo et al. (2012) and Oyedele et al. (2006).

The ANOVA data presented in Table 5 showed that the values of $P=0.966>0.050$ indicated that there is no significant difference in nitrite concentrations from one species of vegetable to another. This is elaborated from their mean and standard deviation as thus; carrot (4.108 \pm 4.059$)$, lettuce $(4.602 \pm 3.639)$, onion (5.772 \pm 2.416$)$, spinach $(5.812 \pm 3.635)$, cabbage (5.957 \pm 5.334$)$, tomato $(5.547 \pm 4.723)$ and okra $(4.325 \pm 3.865)$, respectively. The same Table 5 shows the values of $P=0.263>0.050$ showed

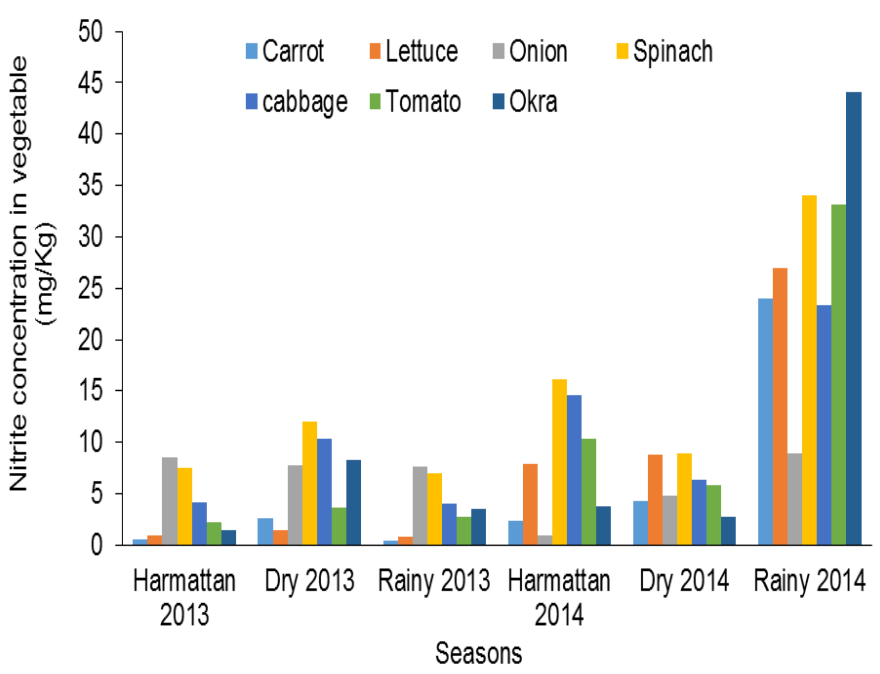

Figure 3. Nitrite concentrations in soil from Kubanni stream channels, Zaria. that there is no significant difference in nitrite levels from one season to another. This can be explained from their mean and standard deviation as thus; harmattan season of the year 2013 (3.910 \pm 3.222$)$, dry season of the year 2013 (3.264 \pm 2.532$)$, rainy season of the year $2013(7.510 \pm 5.541)$, harmattan season of the year 2014 (6.650 \pm 4.595$)$, dry season of the year 2014 $(5.221 \pm 3.000)$ and rainy season of the year $2014(4.406 \pm 2.400)$, respectively. Table 5 also reveals that the values of $P=0.000<$ 0.050 means that there is significant difference in nitrite concentrations in wastewater, soil and vegetables of the sampling sites. This implies that each constituent (wastewater, soil and vegetable) accumulates nitrite at different rate as reflected from their mean and standard deviation as thus; wastewater $(17.353 \pm 13.990)$, soil $(2.594 \pm 2.457)$ and vegetable (5.160 \pm 3.808$)$, respectively. Pearson Product Moment Correlation (PPMC) is presented in Table 6 to establish relationship between nitrite levels in vegetables for the year 2013 and 2014. Statistical analysis showed that the mean with standard deviation of $4.209 \pm 3.508$ in the year 2013 while $6.112 \pm 3.939$ was obtained in the year 2014. It also revealed Pearson correlation $(r)=0.275$, degree of freedom $(d f)=19$ and values of $P=0.228>$ 0.050 showed that there is low relationship between nitrite levels in vegetables for the year 2013 and 2014, respectively.

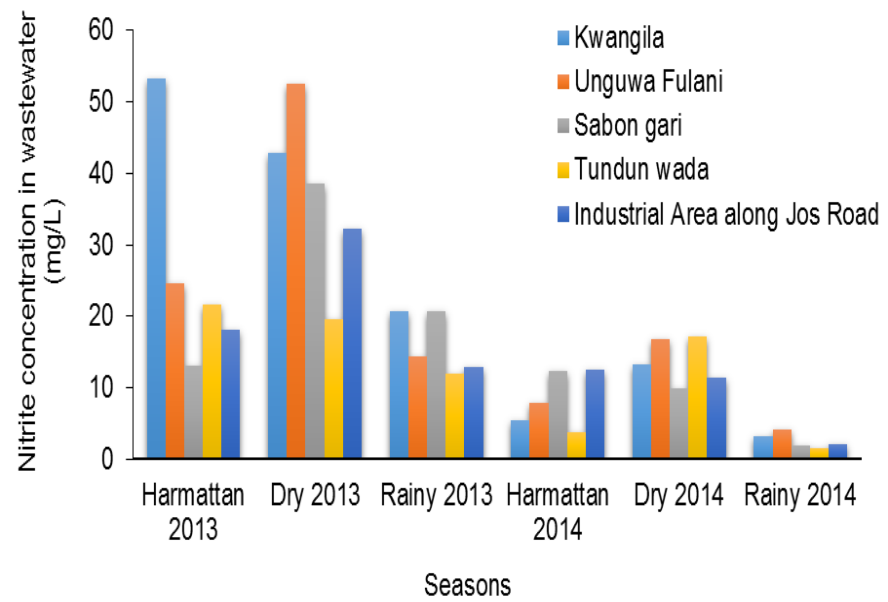

Figure 2. Nitrite Concentrations in wastewater from Kubanni stream channels, Zaria.

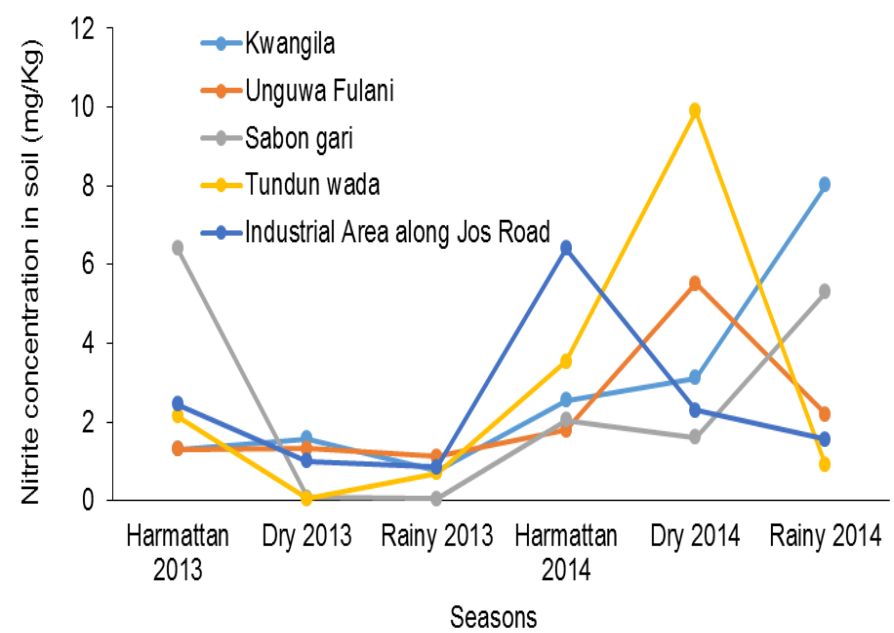

Figure 4. Nitrite concentrations in vegetable from Kubanni stream channels, Zaria. 
Table 1. Analysis of variance (ANOVA) for nitrite in wastewater.

\begin{tabular}{|c|c|c|c|c|c|c|}
\hline Analysis of variance & & Sum of square & df & Mean square & $\mathbf{F}$ & Significance \\
\hline $\begin{array}{l}\text { Nitrite in wastewater } \\
\text { (Locations) }\end{array}$ & $\begin{array}{l}\text { Between groups } \\
\text { Within groups } \\
\text { Total }\end{array}$ & $\begin{array}{l}419.474 \\
5256.792 \\
5676.266\end{array}$ & $\begin{array}{l}4 \\
25 \\
29\end{array}$ & $\begin{array}{l}104.868 \\
210.272\end{array}$ & 0.499 & 0.737 \\
\hline $\begin{array}{l}\text { Nitrite in wastewater } \\
\text { (Seasons) }\end{array}$ & $\begin{array}{l}\text { Between groups } \\
\text { Within groups } \\
\text { Total }\end{array}$ & $\begin{array}{l}894.889 \\
4781.377 \\
5676.266\end{array}$ & $\begin{array}{l}5 \\
24 \\
29\end{array}$ & $\begin{array}{l}178.978 \\
199.224\end{array}$ & 0.898 & 0.498 \\
\hline
\end{tabular}

Table 2. Summary of Pearson product moment correlation for nitrite in wastewater.

\begin{tabular}{lllllll}
\hline Variables & $\boldsymbol{N}$ & $\overline{\boldsymbol{x}}$ & SD & r & df & Significance \\
\hline Nitrite in year 2013 & 15 & 26.481 & 14.043 & 0.399 & 13 & 0.140 \\
Nitrite in year 2014 & 15 & 8.226 & 5.453 & & & \\
\hline
\end{tabular}

Table 3. Analysis of variance (ANOVA) for nitrite in soil.

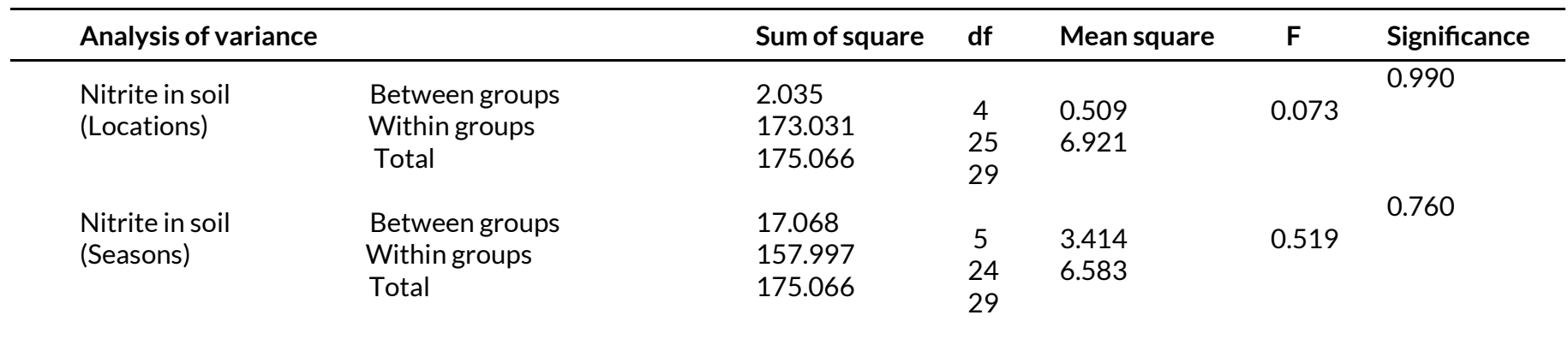

Table 4. Summary of Pearson product moment correlation for nitrite in soil.

\begin{tabular}{lllllll}
\hline Variables & $\boldsymbol{N}$ & $\overline{\boldsymbol{x}}$ & SD & r & df & Significance \\
\hline Nitrite in year 2013 & 15 & 1.407 & 1.548 & -0.290 & 13 & 0.456 \\
Nitrite in year 2014 & 15 & 3.781 & 2.663 & & & \\
\hline
\end{tabular}

Table 5. Analysis of variance (ANOVA) for nitrite in vegetables.

\begin{tabular}{|c|c|c|c|c|c|c|}
\hline Analysis of Variance & & Sum of square & df & Mean square & $\mathbf{F}$ & Significance \\
\hline $\begin{array}{l}\text { Nitrite in vegetable } \\
\text { (Among vegetables) }\end{array}$ & $\begin{array}{l}\text { Between groups } \\
\text { Within groups } \\
\text { Total }\end{array}$ & $\begin{array}{l}22.188 \\
572.312 \\
594.499\end{array}$ & $\begin{array}{l}6 \\
35 \\
41\end{array}$ & $\begin{array}{l}3.698 \\
16.352\end{array}$ & 0.226 & 0.966 \\
\hline $\begin{array}{l}\text { Nitrite in vegetable } \\
\text { (Seasons) }\end{array}$ & $\begin{array}{l}\text { Between groups } \\
\text { Within groups } \\
\text { Total }\end{array}$ & $\begin{array}{l}94.301 \\
500.199 \\
594.499\end{array}$ & $\begin{array}{l}5 \\
36 \\
41\end{array}$ & $\begin{array}{l}18.860 \\
13.894\end{array}$ & 1.357 & 0.263 \\
\hline $\begin{array}{l}\text { Nitrite among } \\
\text { wastewater, soil and } \\
\text { vegetable }\end{array}$ & $\begin{array}{l}\text { Between groups } \\
\text { Within groups } \\
\text { Total }\end{array}$ & $\begin{array}{l}3840.090 \\
6445.831 \\
10285.921\end{array}$ & $\begin{array}{l}2 \\
99 \\
101\end{array}$ & $\begin{array}{l}1920.045 \\
65.109\end{array}$ & 29.490 & 0.000 \\
\hline
\end{tabular}

Table 6. Summary of Pearson product moment correlation for nitrite in vegetable.

\begin{tabular}{lllllll}
\hline Variables & $\boldsymbol{N}$ & $\overline{\boldsymbol{x}}$ & SD & r & df & Significance \\
\hline Nitrite in year 2013 & 21 & 4.209 & 3.508 & 0.275 & 19 & 0.228 \\
Nitrite in year 2014 & 21 & 6.112 & 3.939 & & & \\
\hline
\end{tabular}


Conclusion

The present study showed that nitrite concentrations ranged from $12.05-53.21 \mathrm{mg} / \mathrm{L}$ in the year 2013 and 1.58 - $17.09 \mathrm{mg} /$ $L$ in the year 2014 for wastewater. Soil had concentrations in the range of $0.05-6.40 \mathrm{mg} / \mathrm{kg}$ in the year 2013 and $0.90-9.90$ $\mathrm{mg} / \mathrm{kg}$ for the year 2014 while the vegetable had levels of $3.80-$ $23.65 \mathrm{mg} / \mathrm{kg}$ in the year 2013 and $7.48-27.15 \mathrm{mg} / \mathrm{kg}$ in the year 2014. Further statistical tests indicated no significant difference in nitrite levels across the locations and seasons for wastewater, soil and vegetables evaluated which is attributed to sampling areas are falling within the same vicinity thereby their soil geological formations are similar irrespective of change in seasons. Correlation results for these two years indicated low relationship for wastewater $(r=0.399)$ and vegetables $(r=$ $0.275)$ whereas negative $(r=-0.290)$ relationship noticed for the soil in the year 2013 to that of year 2014. Therefore, irrigating farmland with untreated wastewater has negative consequence on the crops grown with it thereby required periodical monitoring of anion levels along the stream should put in place as to evaluate their environmental impacts in order to assess their possible potential risks.

Open Access: This is open access article distributed under the terms of the Creative Commons Attribution License, which permits unrestricted use, distribution, and reproduction in any medium, provided the original author(s) and the source are credited.

\section{REFERENCES}

Abdu, N., Abdulkadir, A., Agbenin, J.O. and Buerkert, A. (2011). Vertical distribution of heavy metals in wastewater-irrigated vegetable garden soils of three West African cities. Nutrient Cycle in Agroecosystems, 89: 387-397, https:// doi.org/10.1007/s10705-010-9403-3

Ademoroti, C.M.A. (1996). Standard method for water and effluents analysis. Foludex Press Ltd., Ibadan. pp. 118.

Akan, J.C., Abdulrahman, F.I., Ogugbuaja, V.O. and Ayodele, J.T. (2009). Heavy metals and anions levels in some samples of vegetable grown within the vicinity of Challawa industrial area, Kano State, Nigeria. American Journal of Applied Science, 6(3): 534-542, https://doi.org/10.3844 ajassp.2009.534.542

APHA, American Public Health Association (2012). Standard Methods for the Examination of Water and Wastewater, $20^{\text {th }}$ Edition, Washington, DC pp. 2462.

ATSDR, Agency for Toxic Substance and Disease Registry (2011). Nitrate and nitrites. CAS 84145-82-4, 14797-65-0. U.S. Department of Health and Human Services. Public Health Services Unit, Retrieved on $25^{\text {th }}$ October, 2013 from http:// www.atsdr.cdc.gov/toxfaq.html

ATSDR, Agency for Toxic Substance and Disease Registry (2007). 2005 CERCLA Priority List of Hazardous Substance, Retrieved from http://www.atsdr.cdc.gov/cercla/05list.html
Butu, A.W. (2013). Concentration of metal pollutants in river Kubanni, Zaria, Nigeria. Journal of Natural Sciences Research, 3(2): 19-25.

Chapman, D. (1997). Water Quality Assessment. A Guide to the use of Biota, Sediments and Water in the Environmental Monitoring, $2^{\text {nd }}$ Edition, E \& FN Spon, London, pp. 45-90.

Devkota, B. and Schmidt, G.H. (2000). Accumulation of heavy metals in food, plants and grasshoppers from the Taigetos Mountains, Greece. Agriculture, Ecosystem and Environment, 78:85-91, https://doi.org/10.1016/S0167-8809(99)00110-3

Durner, J. and Klessig, D.F. (1999). Nitric oxides as a signal in plants. Current Opinion Plant Biology, 2(5): 369-374.

Farooq, M., Anwar, F. and Rashid, U. (2008). Appraisal of heavy metals grown in the vicinity of an industrial area. Pakistan Journal of Botany, 40(5): 2099-2106.

Grubben, G.J.H. (1976). The cultivation of Amaranthus as a tropical leaf vegetable with special reference to southern Dahomey. Research Royal Tropical Institute, Netherlands. pp. 6.

Guillard, K., Morris, T.F. and Kopp, K.L. (1999). The pre-side dress soil nitrate test and nitrate leaching from corn. Journal of Environmental Quality, 28: 1845-1852, https:// doi.org/10.2134/jeq1999.00472425002800060022x

Heckman, J.R. (2002). In-season soil nitrate testing as a guide to nitrogen management for annual crops. Horticulture Technology, 12: 706 - 710,

Ikemoto, Y., Teraguchi, M. and Kogayashi, Y. (2002). Plasma level of nitrate in congenital heart disease: Comparison with healthy children. Pediatric Cardiology, 23: 132-136, https://doi.org/10.1007/s00246-001-0036-9

Luo, J., Lion, Z. and Yan, X. (1983). Urea transformation and adaptability of three leafy vegetables to urea as a source of nitrogen in hydroponic culture. Journal of Plant Nutrition, 16: 797-812.

McCall, D. and Willumsen, J. (1998). Effects of nitrate, ammonium and chloride application on the yield and nitrate content of soil-grown lettuce. Journal of Horticulture Science and Biotechnology, 73: 698 -703.

Musa, A.S., Elferjani, H.S., Haroun, F.A. and Abdelnabi, F.F. (2009). Determination of available nitrate, phosphate and sulphate in soil samples. International Journal of PharmTech Research, 3: 598-604.

Munson, R.D. and Nelson, W.L. (1990). Principle and Practices in Plants Analysis in "Soil Testing and Plant Analysis" (ed.) Westernan, R.L.; Mandison, SSSA, pp. 359-387.

Oyedele, D.J., Asonugbo, C. and Awotoye, O.O. (2006). Heavy metals in soil and accumulation by edible vegetables after phosphate fertilizer application. Journal of Environmental Agricultural and Food Chemistry, 5: 1446-1453.

Oladeji, S.O. (2017). Evaluation of nickel levels in wastewater, soil and vegetable samples grown along Kubanni stream channels in Zaria, Kaduna State, Nigeria. Archives of Agriculture and Environmental Science, 2(3): 141-147.

Oladeji, S.O. and Saeed, M.D. (2018). Effect of phosphate levels on vegetables irrigated with wastewater. IOP Conference 
Series: Material Science and Engineering, 342(2018)012093, https://doi.org/10.1088/1757-899X/342/1/012093

Oladeji, S.O. (2017). Impact of wastewater on nitrate concentrations in soil and vegetables grown along Kubanni River, Zaria in Kaduna State, Nigeria. Archives of Agriculture and Environmental Science, 2(4): 318-324, https:// doi.org/10.26832/24566632.2017.020413

Radojevic, M. and Bashkin, V.N. (1999). Practical Environmental Analysis. The Royal Society of Chemistry, Cambridge, UK, pp. 466-475.

Reddy, K.S. and Menary, R.C. (1990). Nitrate reductase and nitrate accumulation in relation to nitrate toxicity in Boronia megastigma. Physiology Plantarum, 78(3): 430-434, DOI: https://doi.org/10.1111/j.1399-3054.1990.tb09059.x Robert, J. (1992). Elementary Statistics. $6^{\text {th }}$ Edition, PWS
Publishers, Wadsworth Inc., USA. pp. 120-140.

Santamaria, P. (2006). Nitrate in vegetables: Toxicity, Content, Intake and EC Regulation. Journal of Science, Food and Agriculture, 86: 10-17.

Sodipo, O.A., Abdulrahman, F.I. and Akan, J.C. (2012). Comparative elemental analysis of Solanum macrocarpum (L.) and soil sample from Alau, Borno State, Nigeria. Journal of Research in Environmental Science and Toxicology, 3: 3640.

Thompson, H.C. and Kelly, W.C. (2003).Vegetable Crops. $5^{\text {th }}$ Edition. McGraw Hill Publishing Company Ltd., New-Delhi, pp. 25-35.

Uwah, E.I., Akan, J.C., Moses, E.A., Abah, J. and Ogugbuaja, V.O. (2007). Some anions levels in fresh vegetables in Maiduguri, Borno State, Nigeria. Agricultural Journal, 2(3): 392-396. 